\title{
Living Shorelines Support Nearshore Benthic Communities in Upper and Lower Chesapeake Bay
}

\author{
Theresa M. Davenport ${ }^{1} \cdot$ Rochelle D. Seitz ${ }^{2} \cdot$ Kathleen E. Knick ${ }^{2} \cdot$ Nina Jackson $^{3}$
}

Received: 9 September 2016 / Revised: 5 December 2017 / Accepted: 12 December 2017 / Published online: 27 December 2017

(C) The Author(s) 2017, corrected publication 2019

\begin{abstract}
Human population growth and sea-level rise are increasing the demand for protection of coastal property against shoreline erosion. Living shorelines are designed to provide shoreline protection and are constructed or reinforced using natural elements. While living shorelines are gaining popularity with homeowners, their ability to provide ecological services (e.g., habitat provision and trophic transfer) is not well understood, and information is needed to improve coastal and resource management decision-making. We examined benthic community responses to living shorelines in two case-study subestuaries of Chesapeake Bay using a before-after control-impact study design. At Windy Hill, a bulkhead was removed and replaced by three tombolos, sand fill, and native marsh vegetation. At Lynnhaven, $25 \mathrm{~m}$ of eroding marsh shoreline was stabilized with coir logs, sand fill, and native marsh vegetation. Communities of large $(>3 \mathrm{~mm})$ infauna adjacent to living shorelines at both locations tended to increase in biomass by the end of the study period. Community compositions changed significantly following living shoreline construction at Windy Hill, reflecting a trend toward higher density and biomass of large bivalves at living shorelines compared to pre-construction. Increasing trends in density and biomass of clams and simultaneously decreasing density and decreasing trends in biomass of polychaetes suggest a transition toward stable infaunal communities at living shorelines over time, though longer-term studies are warranted.
\end{abstract}

Keywords BACI $\cdot$ Infauna $\cdot$ Bulkhead $\cdot$ Biomass $\cdot$ Benthic community $\cdot$ Chesapeake Bay

\section{Introduction}

Human population growth has led to shoreline development aimed at protecting against erosion and sea-level rise. Natural wetlands can protect shorelines by attenuating waves, capturing and accreting sediment, reducing erosion, and mitigating

Communicated by Nancy L. Jackson

Electronic supplementary material The online version of this article (https://doi.org/10.1007/s12237-017-0361-8) contains supplementary material, which is available to authorized users.

Theresa M. Davenport

davenport.th@husky.neu.edu

1 Marine Science Center, Northeastern University, 430 Nahant Road, Nahant, MA 01908, USA

2 Virginia Institute of Marine Science, College of William \& Mary, PO Box 1346, Gloucester Point, VA 23062, USA

3 Catalina Island Marine Institute, 1 Toyon Bay Road, Avalon, CA 90704, USA storm surge (Spalding et al. 2014; Pontee et al. 2016; Gittman et al. 2014). The loss of fringing wetlands through shoreline modification may alter the connectivity of land and sea, water flow, and access to shallow-water habitats. Hard structures may lead to loss of intertidal habitats and reduce the esthetic value of the shoreline (Dugan et al. 2008; Walker et al. 2011); thus, the demand is increasing for alternative methods of erosion protection with natural elements (Arkema et al. 2013; Cheong et al. 2013; Narayan et al. 2016).

The lack of information on the impact of shoreline structures on the habitats they replace or modify (Weinstein and Kreeger 2000) makes it difficult for managers to evaluate the effects of such habitat alterations on key ecological species and, consequently, consider ecological impacts in shoreline development regulations. To inform coastal and resource management decisions, more information is needed on the effects of alternative erosion-protection structures such as "living shorelines" (shorelines incorporating natural elements) on living resources and their ecosystem functions (Sutton-Grier et al. 2015; The White House 2015; Narayan et al. 2016).

Shoreline vegetation supports benthic communities by providing energy input to nearshore detritus-based food webs at 
the land-water interface (Burkholder and Bornside 1957; Teal 1962), which contribute to trophic transfer through secondary production (Diaz and Schaffner 1990; Valiela 1995). Several studies suggest that conventional shoreline stabilization (e.g., seawalls and riprap revetments), which often replaces shoreline vegetation, may negatively impact macrofauna in nearby subtidal shallow water habitats (Seitz et al. 2006; Bilkovic et al. 2006; Gittman et al. 2015; Lovall et al. 2017). In a meta-analysis, fauna adjacent to seawalls had lower diversity and abundance than that adjacent to natural habitats (Gittman et al. 2016a). Similar to results for invertebrates, shoreline characteristics and inwater structure can affect fish communities that depend on subtidal infauna (Bilkovic et al. 2005), while larger nekton may take many years to respond (La Peyre et al. 2014). Since shoreline modification can affect both infaunal benthic communities and higher-trophic-level consumers over time, minimizing conventional shoreline development will reduce these negative effects.

Living shorelines may be employed to avoid or mitigate hardening and destruction of the land-water interface and intertidal zone. Living shorelines that are tailored to specific locations and incorporate natural elements to effectively stabilize shorelines are gaining popularity among homeowners as understanding of their function and potential cost-effectiveness increases (Currin et al. 2010; NOAA 2015; Narayan et al. 2016). Natural habitat elements used in living shorelines include marsh grasses, submerged aquatic vegetation, riparian vegetation, coarse woody debris, and oyster reef and shell (Piazza et al. 2005), which are often formed into offshore breakwaters or shoreparallel sills to mimic natural reefs (Erdle et al. 2008; Smith 2008). Living shorelines are hypothesized to perform as well as, if not outperform, conventional methods for erosion control (Currin et al. 2010; Gittman et al. 2014, 2016b), while improving water and habitat quality for nearshore organisms (Davis et al. 2008; Gittman et al. 2016b; Bilkovic et al. 2016), particularly in low-energy environments (Smith 2008). In North Carolina, living shorelines with offshore sills enhanced the nursery habitat and raised nekton abundance and diversity compared to hardened structures and natural salt marshes (Gittman et al. 2016b). These created fringing marshes, acting as marsh edge habitats, can enhance ecosystem functions (Currin et al. 2015). Created marshes can provide fish habitat (Currin et al. 2008), attenuate waves, trap sediment (Leonard et al. 2002; Morgan et al. 2009; Bilkovic et al. 2016; Narayan et al. 2016), and remove groundwater nitrate (Tobias et al. 2001; Burke et al. 2005). The ability of living shorelines to enhance ecological function of the benthos relative to their starting shoreline condition is still little known, though some research has suggested positive effects of living shorelines on benthic abundance and diversity (Bilkovic and Mitchell 2013). Further information on the impact of living shorelines on benthic infauna is sorely needed to inform resource management decisions as coastal communities continue to develop shorelines (Currin et al. 2015).

To better understand biological responses of shallow estuarine benthic infaunal communities to living shoreline construction, we monitored two living shoreline case studies, one in upper and one in lower Chesapeake Bay, using a before-after control-impact (BACI) approach. Living shorelines were constructed to replace a bulkhead in the upper bay and an eroding marsh in the lower bay. The objective of our study was to examine the impacts of living shoreline construction on benthic infaunal density, biomass, taxonomic richness, and species composition.

At both case-study locations, we hypothesized that density, biomass, and richness of infaunal communities would increase at "impact" shorelines after living shoreline construction, relative to control shorelines. Additionally, we hypothesized that living shoreline construction would alter infaunal community composition at impact shorelines, but communities at control shorelines would not change.

\section{Materials and Methods}

\section{Case-Study Locations}

Two case-study locations were selected, one each in the upper (Windy Hill) and lower Chesapeake Bay (Lynnhaven; Fig. 1a). Locations were chosen based on the timing, length $(>20 \mathrm{~m})$, and accessibility $(<1.2 \mathrm{~m}$ in depth at $5 \mathrm{~m}$ from the shoreline at mid-tide) of the living shorelines undergoing construction.

\section{Case Study 1: Upper Chesapeake Bay—Windy Hill}

Windy Hill Farm in Centreville, MD, is located on the Corsica River. In June 2010, a 150-m section of bulkhead was removed and replaced by a living shoreline constructed with a breakwater system built to resemble natural tombolos surrounding lagoons (Fig. 1b, c). Three sills (approx. 12-25 m long by $3 \mathrm{~m}$ wide, $18 \mathrm{~m}$ from the shore) were constructed of cobbles ( $\sim 100 \mathrm{~mm}$ diameter) and gravel ( $\sim 20 \mathrm{~mm}$ diameter $)$ at $0.6 \mathrm{~m}$ depth and connected to the mainland by sandbars. About $50 \%$ of these structures is exposed at MLLW. Marsh grasses (Spartina alterniflora, Spartina patens, and Pacinum virgatum) were planted in late 2010 on the tombolos and along the shoreline, at appropriate elevations covering the project footprint. Post-construction, the living shoreline was $211 \mathrm{~m}$ in length, and the project footprint $>3500 \mathrm{~m}^{2}$. Benthic infauna were collected over 4 years, once before (spring 2010) and three times after (spring 2011, 2012, and 2013) construction 
Fig. 1 a-e Study locations in the upper (Windy Hill) and lower (Lynnhaven) Chesapeake Bay, USA. a Map showing the study locations. At Windy Hill: $\mathbf{b}$ aerial view of the living shoreline just after construction and $\mathbf{c}$ a shoreline view showing marsh grass growth after 15 months (foreground) and the northernmost breakwater sill (background); photo credits, Chesapeake \& Coastal Service, Maryland Department of Natural Resources. At Lynnhaven: $\mathbf{d}$ the construction of the living shoreline and placement of sand fill and e the living shoreline with 10 months of marsh growth; photo credits, D. Stephan

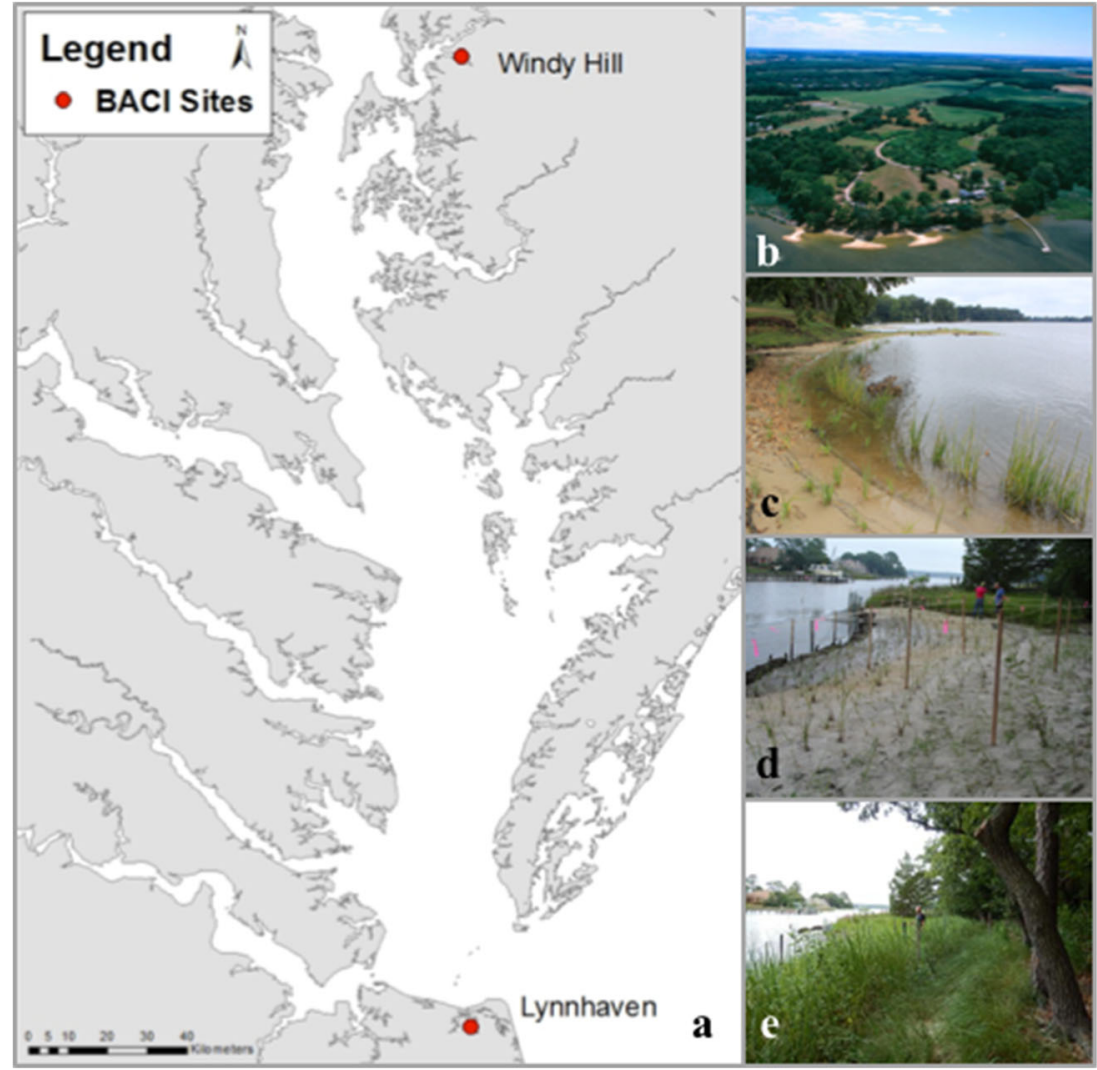

of the living shoreline at three shoreline types (impact $=$ bulkhead converted to living shoreline, bulkhead = bulkhead control, marsh = fringing marsh control). Neighboring shorelines were selected as controls to mimic the impact shoreline both before (bulkhead) and after (marsh) living shoreline construction.

\section{Case Study 2: Lower Chesapeake Bay-Lynnhaven}

Little Haven Bay is located in the Lynnhaven River, Lynnhaven, VA. In July 2012, an eroding sandy bank, at which vegetation was largely lost (hereafter "eroding marsh") was converted to a living shoreline (Fig. 1d, e). Coir logs $(\sim$ $0.3 \mathrm{~m}$ diameter) were staked at a depth of approximately $0.18 \mathrm{~m}$ along $30 \mathrm{~m}$ to create a new marsh toe and stabilize $25 \mathrm{~m}$ of shoreline. The bank was filled with $57 \mathrm{~m}^{3}$ of sand graded to a slope of $0.125 \mathrm{~m}$. Marsh grasses (S. alterniflora, S. patens, and Distichlis spicata) were planted at appropriate elevations spanning the $147-\mathrm{m}^{2}$ project footprint. Benthic infauna were collected over 3 years, once before (spring 2012) and twice after (spring 2013 and 2014) construction of the living shoreline, at two shoreline types (impact = eroding marsh converted to living shoreline, marsh = fringing marsh control). Neighboring marsh shorelines were selected as controls to mimic the impact shoreline after living shoreline construction.

\section{Infaunal Sampling and Physical Data}

To collect large $(>3 \mathrm{~mm}$ ) deep-dwelling benthic infauna, a large PVC core $38 \mathrm{~cm}$ in inner diameter $\left(0.11 \mathrm{~m}^{2}\right)$ was pushed $40 \mathrm{~cm}$ into the sediment and evacuated with a suction apparatus into a 3-mm-mesh bag (Eggleston et al. 1992; Seitz et al. 2006). Samples were bagged, placed on ice in the field, and frozen until processing. In the lab, samples were sorted thoroughly, then double checked for accuracy, and all organisms were transferred to $70 \%$ ethanol, enumerated, and identified to the lowest possible taxonomic level. Organisms were dried at $65{ }^{\circ} \mathrm{C}$ for $48 \mathrm{~h}$, weighed, and then combusted in a muffle furnace at $550{ }^{\circ} \mathrm{C}$ for $4 \mathrm{~h}$ to obtain ash-free dry weight. All sampling took place in spring (May-June), was repeated annually, and replicated in space at each shoreline type $(n=3-7$ replicates).

At each infaunal sampling site, surface salinity, dissolved oxygen (DO), and water temperature were measured using a calibrated YSI Pro-Plus Multi-Parameter Water Quality Meter. Sediment was sampled at each infaunal sampling site using a 2.6-cm-diameter syringe core pushed into the sediment to $5 \mathrm{~cm}$ 
and the percent of various grain sizes determined using a standard wet sieving and pipetting technique (Plumb 1981).

\section{Data Analysis and Interpretation}

Responses in density, biomass, and taxonomic richness of infaunal communities to living shoreline construction were analyzed with linear models (Forrest and Taylor 2002; Schwarz 2015; Ives 2015) using R statistical software (R version 3.4.0, $\mathrm{R}$ Core Team 2017). Density and biomass were converted to per square meter and were $\log _{10}(x+1)$ transformed as needed to satisfy assumptions of normality and homogeneity of variance (Forrest and Taylor 2002; Ives 2015). Fixed effects included in all models were years, shorelines (impact, marsh control, and bulkhead control), and their interaction, which is the effect of interest in BACI designs (Underwood 1994; Smith 2002; McDonald et al. 2000; Schwarz 2015). In our BACI design, interactions of year and shoreline (BACI interactions) indicated impacts of living shoreline construction. Densities and biomasses of clam and polychaete assemblages were also analyzed using the same model structure.

Responses of infaunal community composition, clam assemblage, and polychaete assemblage to living shoreline construction were analyzed using asymmetric, distance-based permutational (non-parametric) multivariate analyses of variance (PERMANOVA) using $\mathrm{R}$ statistical software ( $\mathrm{R}$ version 3.4.0, R Core Team 2017). A small number (0.0001) was added to all community composition data to retain samples with zero animals. Community composition data were square root transformed, and similarities were based on the BrayCurtis dissimilarity calculation. Model structure was identical to that described in univariate analyses.

\section{Results}

\section{Case Study 1: Upper Chesapeake Bay-Windy Hill}

\section{Water Quality and Sediment Grain Size}

Salinity, water temperature, and dissolved oxygen varied similarly among shoreline types (see Supplementary Table A1). In 2011, salinity dropped to 3.6 PSU at all shoreline types (Table A1), consistent with wet meteorological conditions that year. Water temperatures remained within a $5{ }^{\circ} \mathrm{C}$ range throughout the study period, and dissolved oxygen remained normoxic. Percent sand $(62.5 \mu \mathrm{m} \leq$ diameter $\leq 2000 \mu \mathrm{m})$ varied significantly by shoreline $(\mathrm{df}=2, F=10.993$, $p<0.0005)$. The interaction of year and shoreline was not significant $(\mathrm{df}=6, F=2.046, p=0.079)$. Percent fine sediments (diameter $<62.5 \mu \mathrm{m}$, includes silt and clay) differed by year (df $=3, F=3.131, p=0.035)$, but not by shoreline, and the BACI interaction was not significant.

\section{Benthic Community Composition and Analyses}

Twelve individual taxa, including bivalves (Limecola balthica, Rangia cuneata, Ameritella mitchelli, Mya arenaria), polychaetes (Alitta succinea, Eteone heteropoda, Laeonereis culveri), and crustaceans (Cyathura polita, Edotea triloba), were collected at Windy Hill (Table A2). Total infaunal density at all shorelines varied significantly by year (Table A3). At the impact shoreline, density tended to decrease markedly in 2011, one year after living shoreline construction, but tended to increase in subsequent years, matching that at marsh shorelines by 2013 (Fig. 2a). Clam and polychaete densities each varied significantly by year and tended to show contrasting responses to living shorelines, particularly one year after construction (2011) and in the final year of the study (2013). Clam density tended to remain stable at all shorelines from 2010 to 2011, tended to increase slightly at all shorelines in 2012, and tended to increase markedly at the living shoreline compared to the controls in 2013 (Fig. 2b), although the BACI interaction was not significant. Polychaete density at all shorelines varied significantly by year and by shoreline type, with a significant BACI interaction $(p=0.027$; Table A3). Polychaete density decreased markedly one year after construction (2011) at the living shoreline compared to that at control shorelines, and remained low at the living shoreline for the duration of the study (Fig. 2c).

Total infaunal biomass at all the Windy Hill shorelines varied significantly by year (Table A3). Biomass at the impact shoreline tracked that at marsh control shorelines from before to after living shoreline construction, but tended to increase from 2011 through 2013, although the BACI interaction was not significant (Fig. 2d). Infaunal biomass at the impact shoreline doubled from $3.7 \pm 0.8 \mathrm{~g} \mathrm{AFDW} / \mathrm{m}^{2}$ before living shoreline construction to $7.4 \pm 2.3 \mathrm{~g} \mathrm{AFDW} / \mathrm{m}^{2}$ in 2013 , three years after living shoreline construction. Similar to density, clam and polychaete biomasses at Windy Hill showed contrasting trends in response to living shorelines, particularly one year after living shoreline construction (in 2011) and in the final year of the study (2013). Clam biomass tracked the changes in total biomass (Fig. 2e) and varied significantly by year, whereas polychaete biomass differed among shorelines and years, and the BACI interaction had a $p$ value of 0.07 (Table A3). At the living shoreline, clam biomass tended to increase from 2011 to 2012 and 2013, and polychaete biomass tended to decrease one year after living shoreline construction (2011; Fig. 2f). Taxonomic richness at Windy Hill decreased at the impact shoreline one year after living shoreline construction (2011), but it matched richness at the controls thereafter (Fig. 2g), and the BACI interaction was significant $(p=0.009$; Table A3). 
Fig. 2 a-g Impacts of living shoreline construction at Windy Hill over time on a total density of individuals $/ \mathrm{m}^{2}, \mathbf{b}$ density of clams $/ \mathrm{m}^{2}, \mathbf{c}$ density of polychaetes $/ \mathrm{m}^{2}, \mathbf{d}$ total biomass/ $\mathrm{m}^{2}$, e biomass of clams $/ \mathrm{m}^{2}, \mathbf{f}$ biomass of polychaetes $/ \mathrm{m}^{2}$, and $\mathbf{g}$ taxa richness $/ 0.11 \mathrm{~m}^{2}$ within benthic infaunal communities adjacent to impact shorelines (Impact; light gray circles), marsh control shorelines (Marsh; dark gray triangles), and bulkhead control shorelines (Bulkhead; black squares). The dashed line represents the conversion of the impact shoreline from the bulkhead to a living shoreline. Error bars are $1 \mathrm{SE}$; sample sizes per year and shoreline type as in Supplementary Table A1. Y x S designates significant BACI interactions, with interaction $p$ values. For full ANOVA results, see Supplementary Table A3 $\mathbf{a}$

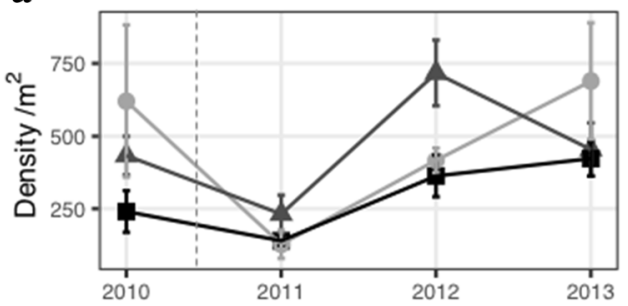

b

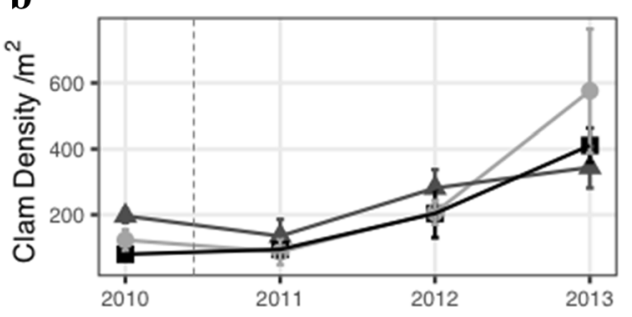

c

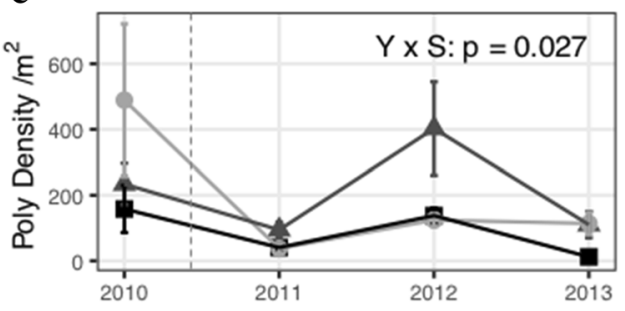

Shoreline

- - Impact

Marsh

Bulkhead d
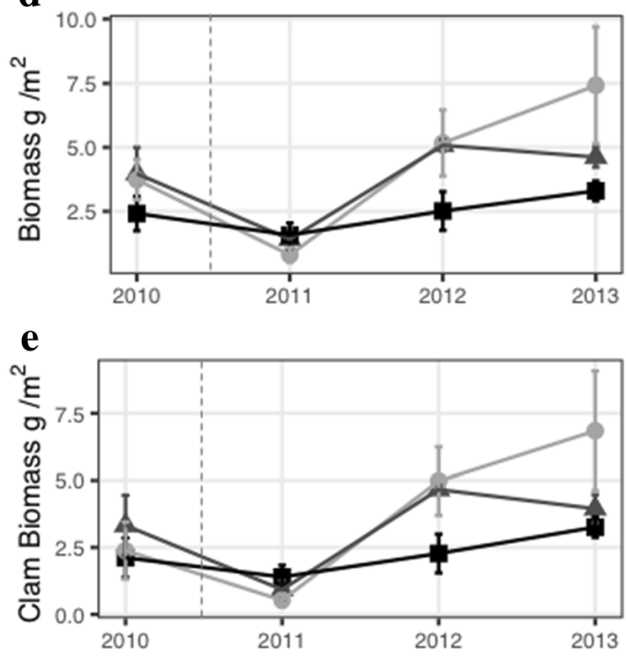

f

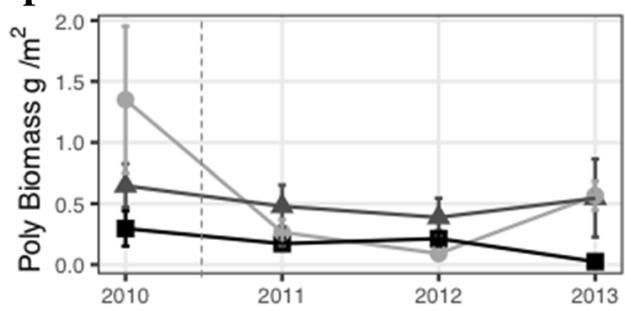

g

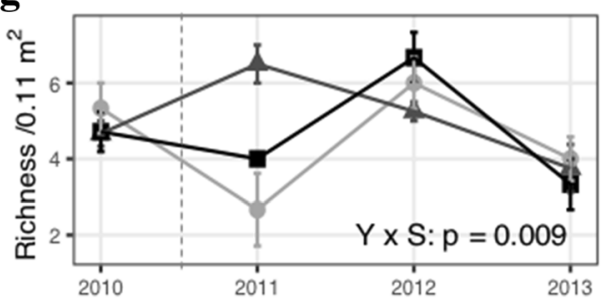

Community composition at Windy Hill differed significantly by year and shoreline with a significant BACI interaction $(p=$ 0.040; Table A3), illustrating that communities varied differentially among shorelines and years in response to living shoreline construction. The clam assemblage reflected this change with a significant BACI interaction ( $p=0.007$; Table A3). Changes in clam assemblage composition reflected increases in abundances of such species as Limecola balthica and Mya arenaria at living shorelines compared to bulkhead controls (Table A2). In contrast, the polychaete assemblage composition did not change with living shoreline construction (Tables A2 and A3).

\section{Case Study 2: Lower Chesapeake Bay_Lynnhaven Bay}

\section{Water Quality and Sediment Grain Size}

Salinity and dissolved oxygen remained largely consistent and normoxic, with no clear patterns across years and shoreline types (Table A4). Water temperature at all shorelines remained consistent throughout the study period, with temperatures at living shorelines tending to be $\sim 2{ }^{\circ} \mathrm{C}$ cooler than control shorelines across all years (Table A4). Percent sand $(62.5 \mu \mathrm{m} \leq$ diameter $\leq 2000 \mu \mathrm{m})$ varied significantly by year ( $\mathrm{df}=2, F=20.0, p<0.0005)$ but not by shoreline (Table A4). In 2013, one year after living shoreline construction, percent sand dropped at both control (Spartina marsh) and living shorelines, whereas two years after construction, percent sand increased at both shorelines (Table A4). Percent fine sediments (diameter $<62.5 \mu \mathrm{m}$, includes silt and clay) differed by year $(\mathrm{df}=2, F=20.000, p<0.0005)$, but not by shoreline, and the BACI interaction was not significant (Table A4).

\section{Benthic Community Composition and Analyses}

Sixteen individual taxa, including bivalves (Limecola balthica, Ameritella mitchelli, Mulinia lateralis, Tageuls plebeius, Ensis leei), polychaetes (Alitta succinea, Glycera 
dibranchiata, Glycinde solitaria, Clymenella torquata, Laeonereis culveri, Loimia medusa), and crustaceans (Cyanthura polita), were collected at Lynnhaven (Table A5). Infaunal density at all Lynnhaven shorelines varied significantly by year but not significantly by shoreline and with no significant BACI interaction (Table A6). Density at the impact shoreline tended to increase in 2013, one year after living shoreline construction, and tended to decrease in 2014 (Fig. 3a). Clam and polychaete densities tended to show contrasting responses at the impact shoreline, particularly one year after living shoreline construction (2013). Clam density at all shorelines varied significantly by year (Table A6) and at the impact shoreline it tended to increase from before (2012) to after living shoreline construction (2013; Fig. 3b), with no significant BACI interaction. Polychaete density for all years differed significantly by shoreline; there was no significant difference by year, and there was a significant BACI interaction ( $p=0.020$; Table A6). At the impact shoreline, polychaete density decreased from before (2012) to after (2013) living shoreline construction compared to density at the control shoreline (Fig. 3c).

Total infaunal biomass at all Lynnhaven shorelines differed significantly by year, but not by shoreline, and the BACI interaction was not significant. Infaunal biomass at the impact shoreline tended to rise from 2012 (before living shoreline construction) to 2013 (one year after construction) and remain constant in 2014 (Fig. 3d). Overall, infaunal biomass at the impact shoreline increased from $10.1 \pm 4.3 \mathrm{~g} / \mathrm{m}^{2}$ in 2012 , before living shoreline construction, to $18.1 \pm 3.4 \mathrm{~g} / \mathrm{m}^{2}$ in 2014 , two years after living shoreline construction. Similar to density, clam and polychaete biomasses also tended to show contrasting responses to the living shoreline, particularly one year after living shoreline construction (2013). Clam biomass at all shorelines differed significantly by year, but not by shoreline, and the BACI interaction was not significant (Table A6). Clam biomass tended to increase from before (2012) to after (2013) construction and then remain constant (Fig. 3e). Polychaete biomass at all shorelines differed significantly by
Fig. 3 a-g Impacts of living shoreline construction at Lynnhaven over time on a total density of individuals $/ \mathrm{m}^{2}, \mathbf{b}$ density of clams $/ \mathrm{m}^{2}$, $\mathbf{c}$ density of polychaetes $/ \mathrm{m}^{2}$, $\mathbf{d}$ total biomass/ $\mathrm{m}^{2}$, e biomass of clams $/ \mathrm{m}^{2}, \mathbf{f}$ biomass of polychaetes $/ \mathrm{m}^{2}$, and $\mathbf{g}$ taxa richness $/ 0.11 \mathrm{~m}^{2}$ within benthic infaunal communities adjacent to impact shorelines (Impact; light gray circles) and marsh control shorelines (Marsh; dark gray triangles). The dashed line represents the conversion of the impact shoreline from eroding marsh to a living shoreline. Error bars are $1 \mathrm{SE}$; sample sizes per year and shoreline type as in Supplementary Table A4. Y x S designates significant $\mathrm{BACI}$ interactions, with interaction $\mathrm{p}$ values. For full ANOVA results, see Supplementary Table A6 a

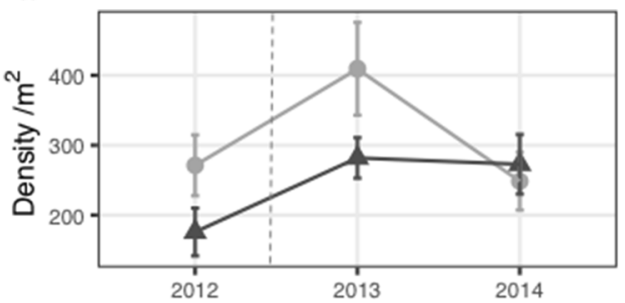

b
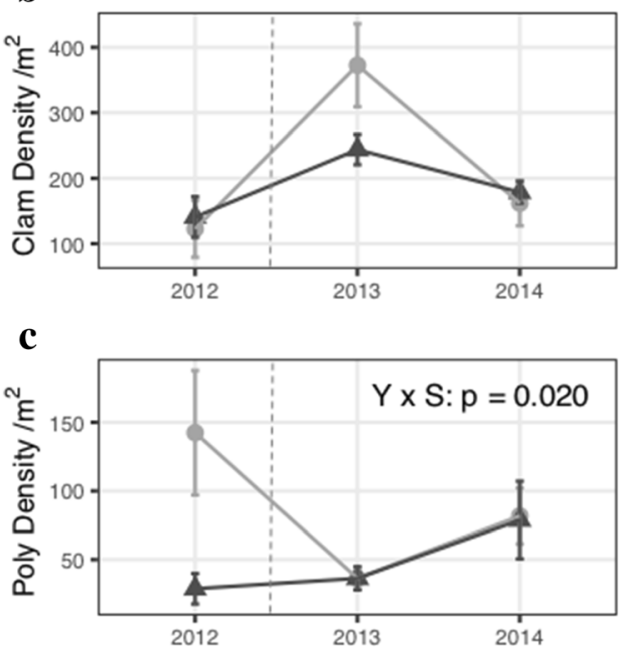

Shoreline

Impact

Marsh d
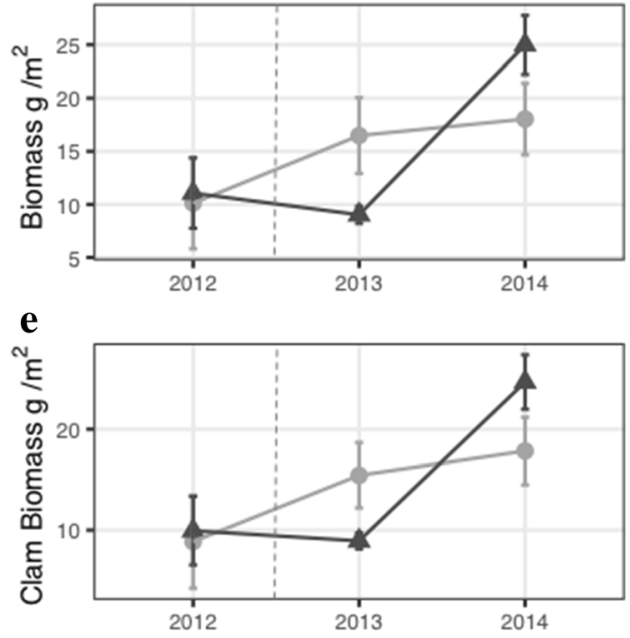

f

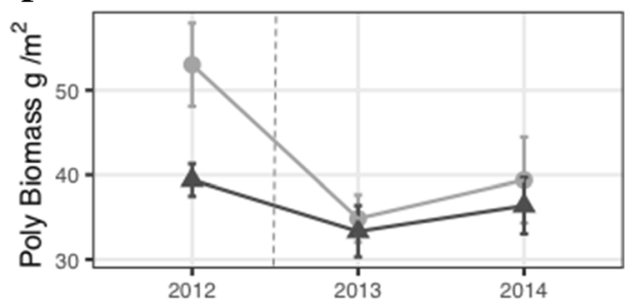

g

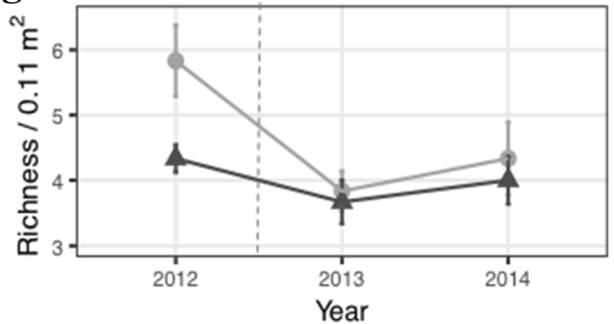


year, tended to decrease from before (2012) to after construction (2013), and then remain constant (Fig. 3f), and the BACI interaction was not significant. Infaunal taxonomic richness at all shorelines varied significantly by year, and the BACI interaction was not significant. Richness tended to decrease at the impact shoreline from before (2012) to one year after (2013) living shoreline construction (Fig. 3g). Following living shoreline construction, richness tended to remain constant between shorelines.

Community composition differed among years and between shorelines, with a BACI interaction $p$ value of 0.074 (Table A6). Differences in community composition may have reflected trends toward increases in species such as Limecola balthica, Leitoscoloplos spp., and the isopod Cyathura polita at impact shorelines after living shoreline construction (Table A5). Clam and polychaete assemblage compositions did not individually differ among shorelines and years, and there were no significant BACI interactions.

\section{Discussion}

Responses of benthic communities to the two living shorelines in our study, either replacing bulkhead or stabilizing eroding marsh, reflect similar patterns and trends. First, biomass tended to increase in response to living shorelines. Second, clam and polychaete assemblages tended to respond differentially to living shorelines. Species composition of clam assemblages changed at Windy Hill, which likely drove the biomass trends. While community composition did not change significantly at Lynnhaven, there was a trend toward increasing densities of clams, which also likely drove the biomass trends. We hypothesized that biomass would increase and community structure would be altered with living shorelines, while the responses of polychaetes and taxonomic diversity were somewhat counter to our initial hypotheses.

\section{Evidence for Benefits to Benthic Communities}

Our study provided evidence for beneficial impacts of living shorelines via increasing trends in biomass at living shorelines by the end of our study period. While BACI interactions were not significant for biomass at our study sites, the increasing trends in biomass that mirrored high biomass at natural marsh controls are biologically meaningful and may indicate a benefit from living shorelines. Infaunal biomass at Windy Hill impact shorelines doubled from $3.7 \pm 0.8 \mathrm{~g} / \mathrm{m}^{2}$ in 2010 to $7.4 \pm 2.3 \mathrm{~g} / \mathrm{m}^{2}$ in 2013 (99\% increase). Additionally, infaunal biomass at both bulkhead and marsh controls in 2013 tended to be lower than at impact (living) shorelines ( $3.3 \pm 0.4$ and $4.6 \pm 0.4 \mathrm{~g} / \mathrm{m}^{2}$, respectively). Although biomass at both bulkhead and marsh shorelines also tended to increase from 2010 to 2013 (16 and 37\% increases, respectively), the increases at controls tended to be smaller than that at impact shorelines. At Lynnhaven, infaunal biomass tended to increase from $10.1 \pm 4.3$ to $18.1 \pm 3.4 \mathrm{~g} / \mathrm{m}^{2}$ (78\% increase) at impact shorelines from 2012 to 2014. Biomass also tended to increase at marsh shorelines over that time frame (11.1 \pm 8.1 to $25.0 \pm$ $6.8 \mathrm{~g} / \mathrm{m}^{2}, 126 \%$ increase).

Increasing trends in biomass likely reflected the increase in the proportion and growth of large bivalves, such as Limeocla balthica (Tables A2 and A5). Limecola balthica is a key infaunal species, and its presence can indicate a generally healthy ecosystem (Long et al. 2014) and improvement in habitat quality at living shorelines. Densities of L. balthica were 568\% higher at the Windy Hill living shoreline in 2013 compared to 2010 . Densities of $L$. balthica were $44 \%$ lower at bulkhead and $48 \%$ lower at marsh shorelines than at impact shorelines in 2013 (Table A2). Densities of L. balthica also tended to increase at the Lynnhaven living shoreline by $92 \%$ from 2012 to 2014 (Table A5). This euryhaline species provides an important food web link between the phytoplankton and detritus on which it feeds and higher trophic levels, such as the economically important blue crab Callinectes sapidus (Lipcius et al. 2007). Thus, increasing trends in biomass from large, deep-dwelling bivalves such as L. balthica may indicate a transition toward a more stable infaunal community with maturation of the living shoreline, which is able to support ecosystem functions (e.g., habitat provision and trophic transfer) at levels that are similar to those of a fringing marsh. The results of this study complement findings of previous studies by suggesting that living shorelines enhance nearshore community structure (Bilkovic and Mitchell 2013; Currin et al. 2015; Gittman et al. 2016b). While we did not address changes to the vegetation, shoreline profile, and hydrodynamics at living shorelines and adjacent controls, growth and maturation of adjacent marsh flora were evident at both study sites, and future study of its influence on benthic communities at living shorelines and adjacent control marshes is needed.

\section{Differential Temporal Responses of Clam and Polychaete Assemblages to Living Shorelines}

Clam and polychaete assemblages showed different trends in response to living shoreline construction at both study sites. At Windy Hill, a transition in community structure at living shorelines was shown through the differential trends in clam density and biomass, which tended to increase, compared to polychaete density, which significantly decreased, and polychaete biomass, which tended to decrease, at living shorelines. In addition, community composition changed differentially among clam assemblages (significant change) and polychaete assemblages (no change) at Windy Hill. At Lynnhaven, a transition in community structure is suggested through increasing trends in clam density and biomass at living shorelines, but decreasing polychaete density and decreasing trends 
in polychaete biomass at living shorelines. While the observed increasing trends in clam density and biomass and decreasing trends in polychaete biomass are not reflected in significant BACI interactions, they represent trends in responses to living shorelines. These differences are biologically meaningful but neither strong nor lasting enough to trigger significant BACI interactions among the natural variation present in the system.

The decreases in polychaete density and in species richness at Windy Hill suggest that this living shoreline construction, with its large footprint and dramatic alteration of the shoreline, was an initial disturbance to infaunal communities. The increasing trend in polychaete biomass in 2013 at the living shoreline suggests polychaetes may be able to recover from this interim disturbance given enough time. This is comparable to disturbances theorized to be responsible for decreases in species richness at high levels of environmental stress (Pearson and Rosenberg 1978; Menge and Sutherland 1987). The responses and trends of infaunal communities in our study suggest that clams and polychaetes respond differentially during succession following the disturbance of living shoreline construction in estuaries, given that clam and polychaete assemblage responses and trends were similar at both case-study sites. Successional dynamics following meso-scale disturbances (such as construction) vary spatially and temporally, depending on several physical and biological processes, such as timing of disturbance, habitat, reproductive periodicity of infauna, population dynamics of the species pool of colonizers, and abiotic and biotic factors (e.g., food and space; Zajac et al. 1998). Estuarine fauna are subject to many stressors and natural variation (e.g., salinity), which makes documenting succession a difficult task, especially as transitory communities (those that occur between pioneer and final communities) are difficult to predict (Pearson and Rosenberg 1978). In spite of the variation inherent in estuaries, at the end of the study period, we documented positive trends in clam assemblages (via density and biomass), accompanied by a change in clam assemblage structure at the Windy Hill study site, and negative responses in polychaete assemblages (via density and decreasing trends in biomass) at both case-study sites. The consistency in responses across our study sites (with different salinities, starting shorelines, and project scales, among other differences) suggests that the two locations are likely demonstrating a successional response to living shoreline construction. The decrease in density and decreasing trends in biomass of polychaetes and simultaneous increasing trends in clam density and biomass suggest a transition toward stable communities at living shorelines as they begin to function as fringing marshes.

The benthic communities at our living shoreline sites are likely to continue to change with time, and reflect the transitional phase of succession described by Pearson and Rosenberg (1978). In spite of the differences among the two case-study sites (salinity, spatial footprint, and starting shoreline condition, among others), trends in infaunal responses were similar among them. While our results cannot be generalized to all living shorelines (particularly given their varied designs and locations), the similarities between our two case studies give us confidence that the community responses in our study provide insight into successional dynamics following living shoreline construction at meso-scales ( $3500 \mathrm{~m}^{2}$ project footprint at Windy Hill; $147 \mathrm{~m}^{2}$ project footprint at Lynnhaven).

Infaunal metrics in our study showed high variability. Studies over longer time scales may help further delineate impacts of living shorelines from increased variance in community metrics in response to stressors (Carpenter and Brock 2006; Scheffer et al. 2009), such as living shoreline construction. Development of long-term benefits from constructed marshes takes time; a minimum of three years is required for any aboveground plant biomass to meet or exceed levels of primary production compared to that of a natural marsh (Craft et al. 2003). In our study, trends in increasing clam density and biomass, indicative of stable benthic communities at living shorelines, did not appear at Windy Hill until 2 or 3 years following construction. Our results suggest that additional monitoring is needed, both before and after living shoreline construction, to differentiate long-term responses of infaunal communities to living shorelines from responses to interim disturbances from living shoreline construction.

\section{Implications for Study Design and Management Decision-Making}

Our study was designed to identify impacts on benthic communities from replacing bulkhead and eroding marsh shorelines with living shorelines. In conjunction with evidence from other studies suggesting living shorelines are able to reduce erosion (Currin et al. 2010; Narayan et al. 2016; Pontee et al. 2016), provide resilience to storm impacts (Swann 2008, Gittman et al. 2014; Narayan et al. 2016), and support infaunal and nekton communities (Bilkovic and Roggero 2008; Davis et al. 2008; Gittman et al. 2016b; Bilkovic and Mitchell 2013; Bilkovic et al. 2016), our study suggests that living shorelines can alter infaunal community composition (to mirror that at fringing marshes). They may boost infaunal density and biomass, particularly of clam assemblages, within a few years. When adapted to site conditions, living shorelines pose an alternative to traditional hardening for shoreline protection and can aid in meeting multiple coastal management goals, including erosion reduction, benthic habitat provision, and trophic transfer.

Acknowledgments We thank M. Miller, E. Wehrle, B. Stephens, and D. Stephens for allowing us to survey their coastal properties and generously sharing their accommodations. The manuscript was significantly improved by constructive comments from Cassie (Bradley) Lovall, 
Jonathan Lefcheck, Gina Ralph, Cassandra Glaspie, and anonymous reviewers. We thank B. Subramanian and the Maryland Department of Natural Resources for their coordination and support on the Windy Hill study location and assistance with field surveys, and staff and students at Virginia Institute of Marine Science, including Heather Richardson, Seth Theuerkauf, and Emily Kimminau, for assistance with field surveys and laboratory processing. The scientific results and conclusions, as well as any views or opinions expressed therein, are those of the author(s) and do not necessarily reflect the views or positions of NOAA or the Department of Commerce. This is contribution number 3713 from the Virginia Institute of Marine Science.

Funding Information This research was funded by a grant to R. Seitz from the National Oceanic and Atmospheric Administration, Center for Sponsored Coastal and Ocean Research (NA09NOS4780221), and the Virginia Institute of Marine Science. T. Davenport also received support from NSF GK-12 (DGE-0840804) and the 2010 Anchor QEA Scholarship.

Open Access This article is distributed under the terms of the Creative Commons Attribution 4.0 International License (http://creativecommons. org/licences/by/4.0/), which permits use, duplication, adaptation, distribution and reproduction in any medium or format, as long as you give appropriate credit to the original author(s) and the source, provide a link to the Creative Commons license and indicate if changes were made.

\section{References}

Arkema, K.K., G. Guannel, G. Verutes, S.A. Wood, A. Guerry, M. Ruckelshaus, P. Kareiva, M. Lacayo, and J.M. Silver. 2013. Coastal habitats shield people and property from sea-level rise and storms. Nature Climate Change 3: 1-6.

Bilkovic, D.M., and M. Mitchell. 2013. Ecological tradeoffs of stabilized salt marshes as a shoreline protection strategy: effects of artificial structures on macrobenthic assemblages. Ecological Engineering 61: 469-481. https://doi.org/10.1016/j.ecoleng.2013.10.011.

Bilkovic, D.M., and M.M. Roggero. 2008. Effects of coastal development on nearshore estuarine nekton communities. Marine Ecology Progress Series 358: 27-39. https://doi.org/10.3354/meps07279.

Bilkovic, D. M., C. H. Hershner, M. R. Berman, K. J. Havens, and D. M. Stanhope. 2005. Evaluating nearshore communities as indicators of ecosystem health. In (Ed) S. A. Bartone, Estuarine indicators. CRC Press. Pp 365-379.

Bilkovic, D.M., M. Roggero, C.H. Hershner, and K.H. Havens. 2006. Influence of land use on macrobenthic communities in nearshore estuarine habitats. Estuaries and Coasts 29 (6B): 1185-1195. https://doi.org/10.1007/BF02781819.

Bilkovic, D.M., M. Mitchell, P. Mason, and K. Duhring. 2016. The role of living shorelines as estuarine habitat conservation strategies. Coastal Management 44 (3): 161-174. https://doi.org/10.1080/08920753. 2016.1160201.

Burke, D. G., E. W. Koch, and J. C. Stevenson. 2005. Assessment of hybrid type shore erosion control projects in Maryland's Chesapeake Bay-phases I \& II, . Maryland Department of Natural Resources Final Report for Chesapeake Bay Trust, Annapolis, MD, pp. 112.

Burkholder, P.R., and G.H. Bornside. 1957. Decomposition of marsh grass by aerobic marine bacteria. Bulletin of the Torrey Botanical Club 84 (5): 366-383. https://doi.org/10.2307/2483113.

Carpenter, S.R., and W.A. Brock. 2006. Rising variance: a leading indicator of ecological transition. Ecology Letters 9: 308-315.
Cheong, S.M., B. Silliman, P.P. Wong, B. van Wesenbeeck, C.K. Kim, and G. Guannel. 2013. Coastal adaptation with ecological engineering. Nature Climate Change 3 (9): 787-791. https://doi.org/10. 1038/nclimate1854.

Currin, C.A., P.C. Delano, and L.M. Valdes-Weaver. 2008. Utilization of a citizen monitoring protocol to assess the structure and function of natural and stabilized fringing salt marshes in North Carolina. Wetlands Ecology and Management 16 (2): 97-118. https://doi. org/10.1007/s11273-007-9059-1.

Currin, C. A., W. S. Chappell, and A. Deaton. 2010. Developing alternative shoreline armoring strategies: the living shoreline approach in North Carolina. In Shipman, H., Dethier, M.N., Gelfenbaum G., Fresh KL, and Dinicola RS (eds), 2010, Puget Sound shorelines and the impacts of armoring - proceedings of a State of the Science Workshop, May 2009: U.S. Geological Survey Scientific Investigations Report 2010-5254, p. 91-102.

Currin, C., J. Davis, L.C. Baron, A.A. Malhotra, and M. Fonseca. 2015. Shoreline change in the New River estuary, North Carolina: rates and consequences. Journal of Coastal Research 31 (5): 1069-1077.

Davis, J.L.D., R.L. Takacs, and R. Schnabel. 2008. Evaluating ecological impacts of living shorelines and shoreline habitat elements: an example from the upper western Chesapeake Bay. In: Erdle, S.Y., J.L.D. Davis, and K.G. Sellner (Eds), Management, policy, science, and engineering of nonstructural erosion control in the Chesapeake Bay: Proceedings of the 2006 living shoreline summit. CRC Publ. 08-164, CRC press, pp 55-61.

Diaz, R.J., and L.C. Schaffner. 1990. The functional role of estuarine benthos. In Perspectives on the Chesapeake Bay, 1990 Advances in Estuarine Sciences, ed. M. Haire and E.C. Krome, 25-56. Gloucester Point, VA: United States Environmental Protection Agency.

Dugan, J.E., D.M. Hubbard, I.F. Rodil, D.L. Revell, and S. Schroeter. 2008. Ecological effects of coastal armoring on sandy beaches. Marine Ecology 29 (s1): 160-170. https://doi.org/10.1111/j.14390485.2008.00231.x.

Eggleston, D.B., R.N. Lipcius, and A.H. Hines. 1992. Density-dependent predation by blue crabs upon infaunal clam species with contrasting distribution and abundance patterns. Marine Ecology Progress Series 85: 55-68. https://doi.org/10.3354/meps085055.

Erdle, S.Y., J.L.D. Davis, K.G. Sellner (Eds.) 2008 Management policy, science and engineering of nonstructural erosion control in the Chesapeake Bay: proceedings of the 2006 Living Shoreline Summit. CRC Publ. 08-164 CRC Press, 152.

Forrest, B.M., and M.D. Taylor. 2002. Assessing invasion impact: Survey design considerations and implications for management of an invasive marine plant. Biological Invasions 4 (4): 375-386. https://doi. org/10.1023/A:1023613428351.

Gittman, R.K., A.M. Popowich, J.F. Bruno, and C.H. Peterson. 2014. Marshes with and without sills protect estuarine shorelines from erosion better than bulkheads during a category 1 hurricane. Ocean and Coastal Management 102: 94-102. https://doi.org/10. 1016/j.ocecoaman.2014.09.016.

Gittman, R.K., F.J. Fodrie, A.M. Popowich, D.A. Keller, J.F. Bruno, C.A. Currin, C.H. Peterson, and M.F. Piehler. 2015. Engineering away our natural defenses: an analysis of shoreline hardening in the US. Frontiers in Ecology and the Environment 13 (6): 301-307. https:// doi.org/10.1890/150065.

Gittman, R.K., S.B. Scyphers, C. S. Smith, I. P. Neylan, and J. H. Grabowski. 2016a. Ecological consequences of shoreline hardening: a meta-analysis. BioScience: biw091. DOI: https://doi.org/10. 1093/biosci/biw091 .

Gittman, R.K., C.H. Peterson, C.A. Currin, F.J. Fodrie, M.F. Piehler, and J.F. Bruno. 2016b. Living shorelines can enhance the nursery role of threatened estuarine habitats. Ecological Applications 26 (1): 249 263. https://doi.org/10.1890/14-0716. 
Ives, A.J. 2015. For testing the significance of regression coefficients, go ahead and log-transform count data. Methods in Ecology and Evolution 6 (7): 828-835. https://doi.org/10.1111/2041-210X. 12386.

La Peyre, M.K., A.T. Humphries, S.M. Casas, and J.F. La Peyre. 2014. Temporal variation in development of ecosystem services from oyster reef restoration. Ecological Engineering 63: 34-44. https://doi. org/10.1016/j.ecoleng.2013.12.001.

Leonard, L.A., P.A. Wren, and R.L. Beavers. 2002. Flow dynamics and sedimentation in Spartina alterniflora and Phragmites australis marshes of the Chesapeake Bay. Wetlands 22 (2): 415-424. https:// doi.org/10.1672/0277-5212(2002)022[0415:FDASIS]2.0.CO;2.

Lipcius, R.N., D.B. Eggleston, K.L. Heck, R.D. Seitz, and J. van Montfrans. 2007. Ecology of postlarvae and young juvenile blue crabs. In The blue crab Callinectes sapidus, ed. V.S. Kennedy and L.E. Cronin, 535-564. College Park, MD: Maryland Sea Grant.

Long, W.C., R.D. Seitz, B.J. Brylawski, and R.N. Lipcius. 2014. Individual, population, and ecosystem effects of hypoxia on a dominant benthic bivalve in Chesapeake Bay. Ecological Monographs 84 (2): 303-327. https://doi.org/10.1890/13-0440.1.

Lovall, C.D., R.D. Seitz and K.E. Knick. 2017. Direct and indirect impacts of shoreline development on shallow-water benthic communities in a depauperate estuarine system. Bulletin of Marine Science 93 (3): 715-741.

McDonald, T.L., W.P. Erickson, and L. Mcdonald. 2000. Analysis of count data from before-after-control-impact studies. Journal of Agricultural, Biological and Environmental Statistics 5 (3): 262279. https://doi.org/10.2307/1400453 .

Menge, B.A., and J.P. Sutherland. 1987. Community regulation: variation in disturbance, competition, and predation in relation to environmental stress and recruitment. American Naturalist 130 (5): 730757. https://doi.org/10.1086/284741 .

Morgan, P.A., D.M. Burdick, and F.T. Short. 2009. The functions and values of fringing salt marshes in northern New England, USA. Estuaries and Coasts 32 (3): 483-495. https://doi.org/10.1007/ s12237-009-9145-0.

Narayan, S., M.W. Beck, B.G. Reguero, I.J. Losada, B. van Wesenbeeck, N. Pontee, J.N. Sanchirico, J.C. Ingram, G.M. Lange, and K.A. Bucks-Copes. 2016. The effectiveness, coasts and coastal protection benefits and natural and nature-based defences. PLoS One 11 (5): 1-17.

National Oceanic and Atmospheric Administration. 2015. Guidance for considering the use of living shorelines. Available at: http://www. habitat.noaa.gov/pdf/noaa guidance for considering the use of living_shorelines_2015.pdfAccessed 2 February 2016.

Pearson, T.H., and R. Rosenberg. 1978. Macrobenthic succession in relation to organic enrichment and pollution of the marine environment. Annual Reviews in Oceanography and Marine Biology 16: 229-311.

Piazza, B.P., P.D. Banks, and M.K. La Peyre. 2005. The potential for created oyster shell reefs as a sustainable shoreline protection strategy in Louisiana. Restoration Ecology 13 (3): 499-506. https://doi. org/10.1111/j.1526-100X.2005.00062.x

Plumb, R.H. 1981. Procedures for handling and chemical analysis of sediment and water samples. Technical Report EPA/CE-81-1. Prepared by Great Lakes Laboratory, State University College at Buffalo, Buffalo, NY for the US Environmental Protection Agency/Corps of Engineers Technical Committee on criteria for dredged and fill material: Environmental Laboratory, US Army Waterways Experiment Station. Vicksburg, MS pp 403

Pontee, N., S. Narayan, M.W. Beck, and A.H. Hoskin. 2016. Naturebased solutions: lessons from around the world. Proceedings of the Institution of Civil Engineers-Maritime Engineering 169 (1): 29 36. https://doi.org/10.1680/jmaen.15.00027.
R Core Team. 2017. R: a language and environment for statistical computing. Vienna, Austria: R Foundation for Statistical Computing URL https://www.R-project.org/.

Scheffer, M., J. Bascompte, W.A. Brock, V. Brovkin, S.R. Carpenter, V. Dakos, H. Held, E.H. van Nes, M. Rietkerk, and G. Sugihara. 2009. Early-warning signals for critical transitions. Nature 461 (7260): 53-59. https://doi.org/10.1038/nature08227.

Schwarz, C. J. 2015. Analysis of BACI experiments. In Course notes for beginning and intermediate statistics. Available at http://www.stat. sfu.ca/ cschwarz/CourseNotes. Accessed 30 June 2016.

Seitz, R.D., R.N. Lipcius, N.H. Olmstead, M.S. Seebo, and D.M. Lambert. 2006. Influence of shallow-water habitats and shoreline development upon abundance, biomass, and diversity of benthic prey and predators in Chesapeake Bay. Marine Ecology Progress Series 326: 11-27. https://doi.org/10.3354/meps326011.

Smith, E.P. 2002. BACI design. In Encyclopedia of envirometrics, ed. Abdel H. El-Shaarawi and Walter W. Piegorsch, Wiley Online Library: 141-148.

Smith, K.M. 2008. Integrating habitat and shoreline dynamics into living shoreline applications. In: Erdle, S.Y., J.L.D. Davis, and K.G. Sellner (Eds). Management policy, science and engineering of nonstructural erosion control in the Chesapeake Bay: proceedings of the 2006 living shoreline summit. CRC Publ. 08-164, CRC press, pp. 911.

Spalding, M.D., A.L. McIvor, M.W. Beck, E.W. Koch, I. Möller, D.J. Reed, P. Rubinoff, T. Spencer, T.J. Tolhurst, T.V. Wamsley, B.K. van Wesenbeeck, E. Wolanski, and C.D. Woodroffe. 2014. Coastal ecosystems: a critical element of risk reduction. Conservation Letters 7 (3): 293-301. https://doi.org/10.1111/conl.12074.

Sutton-Grier, A.E., K. Wowk, and H. Bamford. 2015. Future of our coasts: the potential for natural and hybrid infrastructure to enhance the resilience of our coastal communities, economies and ecosystems. Environmental Science \& Policy 51: 137-148. https://doi.org/ 10.1016/j.envsci.2015.04.006.

Swann, L. 2008. The use of living shorelines to mitigate the effects of storm events on Dauphin Island, Alabama, USA. American Fisheries Society Symposium. Vol. 64. No. 11.

Teal, J.M. 1962. Energy flow in the salt marsh ecosystem of Georgia. Ecology 43 (4): 614-624. https://doi.org/10.2307/1933451.

The White House. 2015. Incorporating natural infrastructure and ecosystem services in federal decision-making. Available at: https://www. whitehouse.gov/blog/2015/10/07/incorporating-naturalinfrastructure-and-ecosystem-services-federal-decision-making. Accessed 10 October 2015

Tobias, C.R., S.A. Macko, I.C. Anderson, E.A. Canuel, and J.W. Harvey 2001. Tracking the fate of a high concentration groundwater nitrate plume through a fringing marsh: a combined groundwater tracer and in situ isotope enrichment study. Limnology and Oceanography 46 (8): 1977-1989. https://doi.org/10.4319/lo.2001.46.8.1977.

Underwood, A.J. 1994. On beyond BACI: sampling designs that might reliably detect environmental disturbances. Ecological Applications 4 (1): 3-15. https://doi.org/10.2307/1942110.

Valiela, I. 1995. Marine ecological processes. 2nd ed. New York: Springer Science +Business Media, LLC. https://doi.org/10.1007/ 978-1-4757-4125-4.

Walker, R., B. Bendell, and L. Wallendorf. 2011. Defining engineering guidance for living shoreline projects. Coastal Engineering Practice 1064-1077. Doi: https://doi.org/10.1061/41190(422)86.

Weinstein, M.P., and D.A. Kreeger. 2000. Concepts and controversies in tidal marsh ecology, 542. Dordrecht: Kluwer Academic Publishers. https://doi.org/10.1007/0-306-47534-0.

Zajac, R.N., R.B. Whitlatch, and S.F. Thrush. 1998. Recolonization and succession in soft-sediment infaunal communities: the spatial scale of controlling factors. Hydrobiologia 375 (376): 227-240. 